\title{
CEPHALOZIELLA KONSTANTINOVAE (CEPHALOZIELLACEAE, MARCHANTIOPHYTA), A NEW LEAFY LIVERWORT SPECIES FROM RUSSIA AND MONGOLIA IDENTIFIED BY INTEGRATIVE TAXONOMY
}

\author{
Yuriy S. MAmontov ${ }^{1} \&$ Anna A. Vilnet
}

\begin{abstract}
In the course of a taxonomic study of the genus Cephaloziella (Spruce) Schiffn. (Cephaloziellaceae, Marchantiophyta) in Asia, the new species Cephaloziella konstantinovae Mamontov \& Vilnet, sp. nov., from the eastern regions of Russia and from the Republic of Mongolia was discovered. The new species is formally described and illustrated here. Morphologically it is similar to $C$. divaricata var. asperifolia (Taylor) Damsh., but differs in its leaf shape and thin-walled, inflated stem and leaf cells. The new species can be distinguished from other Cephaloziella taxa by the following characters: ( $i$ ) female bracts entirely free from each other and from bracteole, (ii) perianth campanulate, (iii) cells of perianth mouth subquadrate, (iv) capsule spherical, $(v)$ seta with 8-10+4-6-seriate morphology, and (vi) elaters with 1-2 spiral bands. Molecular phylogenetic analyses of nrITS1-5.8S-ITS2 and chloroplast $t r n \mathrm{~L}-\mathrm{F}$ sequences from 63 samples (34 species, 23 genera) confirm the taxonomical status of the new species. Five specimens of C. konstantinovae form a clade placed sister to a clade of C. elachista (J. B. Jack) Schiffn. and C. rubella (Nees) Warnst.
\end{abstract}

Key words: Cephaloziella konstantinovae, distribution, ecology, new species, Hepaticae, taxonomy, ITS1-2 nrDNA, trnL-F cpDNA

Yuriy S. Mamontov, Polar-Alpine Botanical Garden-Institute, Kola Scientific Centre, Russian Academy of Sciences, 184256, Kirovsk, Russia; Komarov Botanical Institute, Russian Academy of Sciences, 2 Prof. Popov St., 184209, St. Petersburg, Russia; Tsitsin Main Botanical Garden, Russian Academy of Sciences, Botanicheskaya 4, 127276, Moscow, Russia; e-mail: yur-mamontov@yandex.ru Anna A. Vilnet, Polar-Alpine Botanical Garden-Institute, Kola Scientific Centre, Russian Academy of Sciences, 184256, Kirovsk, Russia; e-mail: anya_v@list.ru

\section{INTRODUCTION}

Schiffner (1893) established the leafy liverwort genus Cephaloziella (Spruce) Schiffn. to accommodate species of minute size having ventral and lateral branches, small leaf and stem cells, and occasionally underleaves. Schiffner included 20 species in the genus. Cephaloziella is virtually cosmopolitan; its species occur on rotten wood, peat bogs, soil and rocks, but a few taxa in tropical forests are corticolous (Schuster 2002).

The genus is the largest in the family Cephaloziellaceae, with 80-90 species and infraspecific taxa (Söderström et al. 2016). Its taxonomy is considered notoriously difficult due to the small size of the species and their reduced morphology, as well as high ecological plasticity and morphological

\footnotetext{
1 Corresponding author
}

variation. The taxonomy of Cephaloziellaceae has been studied mainly for regional treatments, and authors disagree on circumscription of taxa and evaluation of diagnostic characters (e.g., Arnell 1963; Damsholt 2002; Fulford 1976; Jones 1960; Kitagawa 1965, 1969; Paton 1999; Schumacker \& Váňa 2005; Schuster 1969, 1971, 1980, 1988, 1995, 1996, 2002; Schuster \& Damsholt 1974; Udar \& Nath 1976; Schljakov 1979; Udar \& Kumar 1980, 1982). The most recently described species of the genus is Cephaloziella biokoensis Váňa \& F. Muell. from Equatorial Guinea (Váňa \& Müller 2003).

Recently intensified floristic studies in remote regions of Russia - the Arctic, Caucasus, Siberia and the Far East - produced new records for a number of Cephaloziella species (Konstantinova et al. 2009), allowed revision of numerous 
specimens, and confirmed some opinions of hepaticologists on the circumscription of several taxa. Here we apply an integrative approach, considering evidence from DNA sequence variation as well as morphology, ecology and phytogeography, with a special focus on some morphologically unique specimens collected by the senior author in the Trans-Baikal Region of Siberia. These specimens resembled Cephaloziella but showed some morphological overlap with Scapaniaceae+Anastrophyllaceae in branching mode and generative features. Phylogenetic analyses of nuclear ribosomal ITS and chloroplast DNA trnL-F sequences support the suggestion that these Trans-Baikalian plants belong to Cephaloziella and are distinct from all putative relatives; hence they are described as a new species, Cephaloziella konstantinovae.

\section{MATERIALS AND METHODS}

\section{TAXON SAMPLING}

Species representing the families and genera of Jungermanniales suborder Cephaloziineae (Crandall-Stotler et al. 2009) were chosen to test the morphology-based attribution of the new species to Cephaloziella. A total of 63 accessions representing 34 species were used for this study (Table 1). We analyzed 12 species (41 samples) from the family Cephaloziellaceae, 10 species (10 samples) from Scapaniaceae, 8 species (8 samples) from Anastrophyllaceae, 2 species (2 samples) from Cephaloziaceae, and 2 species ( 2 samples) from Odontoschismataceae. We chose Cephalozia affinis Lindb. ex Steph. as outgroup taxon based on the phylogenetic hypotheses presented by Feldberg et al. (2013).

The ingroup includes 11 taxa from the genus $\mathrm{Ce}$ phaloziella and one species of the genus Cylindrocolea R. M. Schust (Cephaloziellaceae). Ingroup taxa are represented by multiple accessions from different regions. The nucleotide data for 9 specimens were taken from earlier studies and downloaded from GenBank (Vilnet et al. 2012; Bakalin \& Vilnet 2014). DNA vouchers are listed in Table 1, including GenBank accession numbers and voucher details.

\section{DNA ISOLATION, PCR AMPLIFICATION AND DNA} SEQUENCING

DNA was extracted from dried liverwort tissue using the NucleoSpin Plant Kit (Macherey-Nagel, Germany). Amplification and sequencing were performed using primers suggested by White et al. (1990) for nrITS1-2 and Taberlet et al. (1991) for trnL-F. PCRs were carried out in $20 \mu \mathrm{l}$ volumes according to the following procedure: $3 \mathrm{~min}$ at $94^{\circ} \mathrm{C}, 30$ cycles $\left(30 \mathrm{~s} 94^{\circ} \mathrm{C}, 40 \mathrm{~s} 56^{\circ} \mathrm{C}\right.$, $60 \mathrm{~s} 72^{\circ} \mathrm{C}$ ) and $2 \mathrm{~min}$ extension time at $72^{\circ} \mathrm{C}$. Amplified fragments were visualized on $1 \%$ agarose TAE gels by EthBr staining, purified using the GFX ${ }^{\mathrm{TM}}$ PCR DNA and Gel Band Purification Kit (Amersham Biosciences, USA), and then used as a template in sequencing reactions with the ABI Prism BigDye Terminator Cycle Sequencing Ready Reaction Kit (Applied Biosystems, USA) following the standard protocol for the 3100 Avant Genetic Analyzer (Applied Biosystems, USA).

\section{PHYLOGENETIC ANALYSIS}

Two datasets (ITS1-2, trnL-F) were automatically aligned in BioEdit 7.0.1 (Hall 1999) using the ClustalW option and then manually corrected. The preliminary phylogenetic analyses revealed no incongruence between the nuclear and the chloroplast DNA datasets; hence they were combined. Lacking sequences were coded as missing.

The ITS1-2+trnL-F dataset was analyzed using Bayesian inference (BA) implemented in MrBayes 3.2.1 (Ronquist et al. 2012), and by the maximum parsimony method (MP) with NONA under the WinClada shell (Goloboff 1994; Nixon 2002).

The ModelGenerator program (Keane et al. 2006) determined the GTR $+\mathrm{I}+\Gamma$ model as the best-fit evolutionary model of nucleotide substitutions for the combined alignment. In the BA, four partitions of the combined alignment (ITS1-2, trnL-F) were separately assigned the GTR $+\mathrm{I}+\Gamma$ model, and gamma distributions were approximated using four categories. Two independent runs of the Metropolis-coupled MCMC were used to sample parameter values in proportion to their posterior probability. Each run included three heated chains and one unheated chain, and the two starting trees were chosen randomly. The number of generations was $10,000,000$, and trees were saved once every $10,000^{\text {th }}$ generation. Average standard deviation of split frequencies between two runs was 0.009191 . Bayesian posterior probabilities were calculated from trees sampled after burn-in (Fig. 1).

Jackknife support was calculated in NONA for 1000 replications (number of search reps 10, hold 10, max tree 100, do max) and shown in Figure 2.

Due to the unusual morphology of the studied Trans-Baikalian plants here assigned to Cephaloziella konstantinovae, Bayes factor comparison was additionally used to test whether the new species could be related to Anastrophyllaceae or Scapaniaceae rather 
Table 1. List of taxa, voucher specimens and GenBank accession numbers. The sequences from our previous study are in italics. Initial species identifications from herbarium vouchers are indicated for specimens reclassified in this study based on results of DNA analyses.

\begin{tabular}{|c|c|c|c|}
\hline \multirow{2}{*}{ Taxon name } & \multirow{2}{*}{ Voucher specimens } & \multicolumn{2}{|c|}{ GenBank accession number } \\
\hline & & ITS1-2 & trnL-F \\
\hline $\begin{array}{l}\text { Alobiellopsis parvifolia } \\
\text { (Steph.) R. M. Schust. }\end{array}$ & Japan, Bryophytes of Asia Fasc. 8, No. 191 (KPABG) & JX629894 & JX630020 \\
\hline $\begin{array}{l}\text { Barbilophozia barbata } \\
\text { (Schmidel ex Schreb.) } \\
\text { Loeske }\end{array}$ & Netherlands, Konstantinova 3b-5-99 (KPABG) & EU791779 & EU791676 \\
\hline $\begin{array}{l}\text { Cephalozia affinis Lindb. } \\
\text { ex Steph. }\end{array}$ & $\begin{array}{l}\text { Russia, Republic of Adygeya, Konstantinova K473-2-07 } \\
\text { (KPABG) }\end{array}$ & JX629827 & JX629952 \\
\hline $\begin{array}{l}\text { Cephaloziella divaricata } \\
\text { (Sm.) Schiffn. }\end{array}$ & $\begin{array}{l}\text { Russia, Sakhalin Province, Sakhalin I., Bakalin S-24-21-09 } \\
\text { (KPABG) }\end{array}$ & KF805881 & KF805923 \\
\hline $\begin{array}{l}\text { C. elachista (J. B. Jack) } \\
\text { Schiffn. }\end{array}$ & $\begin{array}{l}\text { Russia, Khanty-Mansi Autonomous Area 1, Kukurichkin } \\
\text { OP1VN607/1 (KPABG), published as C. rubella in Vilnet } \\
\text { et al. (2012) }\end{array}$ & JX629919 & JX630048 \\
\hline C. elachista & $\begin{array}{l}\text { Russia, Khanty-Mansi Autonomous Area 2, Kukurichkin } \\
\text { OP1VN607/7 (KPABG), published in Vilnet et al. (2012) }\end{array}$ & JX629918 & JX630047 \\
\hline $\begin{array}{l}\text { C. hampeana (Nees) Schiffn. } \\
\text { ex Loeske }\end{array}$ & $\begin{array}{l}\text { Russia, Kamchatka Territory 1, Bakalin 77-14-01-VB } \\
\text { (as C. uncinata, KPABG) }\end{array}$ & KF805866 & KF805899 \\
\hline C. hampeana & $\begin{array}{l}\text { Russia, Kamchatka Territory 2, Bakalin 98-4-01-VB } \\
\text { (as C. subdentata, KPABG) }\end{array}$ & KF805865 & KF805897 \\
\hline C. hampeana & $\begin{array}{l}\text { Russia, Murmansk Province, Konstantinova 182-3 } \\
\text { (as C. subdentata, KPABG) }\end{array}$ & KF805864 & KF805898 \\
\hline C. kiaeri (Austin) Douin & Borneo, Kinabalu, Konstantinova K-8-4 (KPABG) & KF805888 & KF805935 \\
\hline C. kiaeri & Japan, Bryophyte Selecta Exsiccatae, No. 1218 (KPABG) & KF805886 & KF805934 \\
\hline C. kiaeri & Republic of Korea, Bakalin Kor-2-14-09 (KPABG) & KF805887 & KF805933 \\
\hline $\begin{array}{l}\text { C. konstantinovae Mamontov } \\
\text { \& Vilnet, sp. nov. }\end{array}$ & Russia, Trans-Baikal Territory 1, Afonina 4006-5 (KPABG) & KF805882 & KF805924 \\
\hline C. konstantinovae & $\begin{array}{l}\text { Russia, Trans-Baikal Territory 2, Afonina 4006-6 (KPABG), } \\
\text { published as C. aspericaulis in Bakalin \& Vilnet (2014) }\end{array}$ & KF471666 & KF471664 \\
\hline C. konstantinovae & Russia, Trans-Baikal Territory 3, Afonina 6010-1 (KPABG) & KF805883 & KF805925 \\
\hline C. konstantinovae & $\begin{array}{l}\text { Russia, Trans-Baikal Territory 4, Afonina 05307-7 (KPABG), } \\
\text { (published as C. aspericaulis in Vilnet et al. 2012) }\end{array}$ & JX629917 & JX630044 \\
\hline C. konstantinovae & Russia, Trans-Baikal Territory 5, Mamontov 169-5 (KPABG) & KF805884 & KF805926 \\
\hline $\begin{array}{l}\text { C. microphylla (Steph.) } \\
\text { Douin }\end{array}$ & $\begin{array}{l}\text { Republic of Korea 1, Hepaticae Korea Exsiccatae Fasc. II, } \\
\text { No. } 23 \text { (KPABG) }\end{array}$ & KF805889 & KF805937 \\
\hline C. microphylla & $\begin{array}{l}\text { Republic of Korea 2, Hepaticae Korea Exsiccatae Fasc. I, } \\
\text { No. } 29 \text { (KPABG) }\end{array}$ & KF805890 & KF805938 \\
\hline C. rubella (Nees) Warnst. & Russia, Altai Territory, Mamontov 214-14 (KPABG) & KF805885 & KF805927 \\
\hline C. rubella & $\begin{array}{l}\text { Russia, Republic of Altai, Mamontov 330-5-1 (as C. elegans, } \\
\text { KPABG) }\end{array}$ & KF853559 & KF853560 \\
\hline C. rubella & $\begin{array}{l}\text { Russia, Trans-Baikal Territory, Afonina } 45907 \text { (as C. arcto- } \\
\text { gena, KPABG), published in Vilnet et al. (2012) }\end{array}$ & JX629916 & JX630045 \\
\hline C. spinicaulis Douin & Russia, Primorsky Territory, Bakalin P-63-3-08 (KPABG) & KF805896 & KF805947 \\
\hline C. spinicaulis & $\begin{array}{l}\text { Japan, Deguchi, Exsiccatae Fasc. 5, No. } 119 \text { (published in } \\
\text { Vilnet et al. 2012) }\end{array}$ & JX629922 & JX630043 \\
\hline $\begin{array}{l}\text { C. stellulifera } \\
\text { (Taylor) Schiffn. }\end{array}$ & $\begin{array}{l}\text { Netherlands, Konstantinova le-2-99(KPABG), published in } \\
\text { Vilnet } \text { et al. (2012) }\end{array}$ & JX629923 & JX630042 \\
\hline C. turneri (Hook.) Müll. Frib. & $\begin{array}{l}\text { Russia, Krasnodar Territory, Ignatov \& Ignatova 02-24a } \\
\text { (KPABG) }\end{array}$ & KF805892 & KF805944 \\
\hline
\end{tabular}


Table 1. Continued.

\begin{tabular}{|c|c|c|c|}
\hline \multirow{2}{*}{ Taxon name } & \multirow{2}{*}{ Voucher specimens } & \multicolumn{2}{|c|}{ GenBank accession number } \\
\hline & & ITS1-2 & trnL-F \\
\hline C. varians (Gottsche) Steph. & Norway, Svalbard 1, Konstantinova K78-1-06 (KPABG) & $\begin{array}{l}\text { KF805877 (ITS1) } \\
\text { KF805863 (ITS2) }\end{array}$ & KF805914 \\
\hline C. varians & $\begin{array}{l}\text { Norway, Svalbard 2, Konstantinova K115-02 (as C. grimsu- } \\
\text { lana, KPABG) }\end{array}$ & KF805878 & KF805915 \\
\hline C. varians & $\begin{array}{l}\text { Norway, Svalbard 3, Konstantinova K130-2-04 (as C. unci- } \\
\text { nata, KPABG) }\end{array}$ & KF805880 & KF805920 \\
\hline C. varians & $\begin{array}{l}\text { Russia, Altai Territory, Mamontov 219-5 (as C. divaricata, } \\
\text { KPABG) }\end{array}$ & $\begin{array}{l}\text { KF805876 (ITS1) } \\
\text { KF805862 (ITS2) }\end{array}$ & KF805912 \\
\hline C. varians & $\begin{array}{l}\text { Russia, Republic of Karachaevo-Cherkessia 1, Konstantinova } \\
\text { K515-1-05 (as C. divaricata, KPABG) }\end{array}$ & KF805874 & KF805908 \\
\hline C. varians & $\begin{array}{l}\text { Russia, Republic of Karachaevo-Cherkessia 2, Konstantinova } \\
K 517-2-05 \text { (as C. divaricata, KPABG) }\end{array}$ & KF805873 & KF805907 \\
\hline C. varians & $\begin{array}{l}\text { Russia, Kamchatka Territory, Bakalin K-105-5-03 (KPABG) } \\
\text { (published in Vilnet et al. 2012) }\end{array}$ & JX629924 & JX630051 \\
\hline C. varians & $\begin{array}{l}\text { Russia, Murmansk Province, Konstantinova } K \text { 8-2-12 } \\
\text { (KPABG) }\end{array}$ & $\begin{array}{l}\text { KF805871 (ITS1) } \\
\text { KF805861 (ITS2) }\end{array}$ & KF805904 \\
\hline C. varians & $\begin{array}{l}\text { Russia, Magadan Province, Bakalin Mag-7-40-10 (as C. spi- } \\
\text { nigera, KPABG) }\end{array}$ & KF805872 & KF805905 \\
\hline C. varians & $\begin{array}{l}\text { Russia, Sakhalin Province, Sakhalin I., Bakalin S-58-3-09 } \\
\text { (as C. divaricata var. asperifolia, KPABG) }\end{array}$ & KF805879 & KF805917 \\
\hline C. varians & $\begin{array}{l}\text { Russia, Trans-Baikal Territory 2, Afonina } 07408 \text { (as C. divari- } \\
\text { cata, published in Vilnet et al. 2012, KPABG) }\end{array}$ & JX629921 & JX630050 \\
\hline C. varians & $\begin{array}{l}\text { Russia, Trans-Baikal Territory 3, Afonina A1810 (KPABG), } \\
\text { published as C. polystratosa in Bakalin \& Vilnet (2014) }\end{array}$ & KF471665 & JX630046 \\
\hline C. varians & Russia, Trans-Baikal Territory 4, Afonina A2410 (KPABG) & KF805867 & KF805900 \\
\hline C. varians & $\begin{array}{l}\text { Russia, Trans-Baikal Territory 5, Afonina A3010 (as C. di- } \\
\text { varicata, KPABG) }\end{array}$ & KF805870 & KF805903 \\
\hline C. varians & $\begin{array}{l}\text { Russia, Trans-Baikal Territory 6, Afonina A4805 (as C. poly- } \\
\text { stratosa, KPABG, published in Vilnet et al. 2012) }\end{array}$ & JX629920 & JX630049 \\
\hline C. varians & $\begin{array}{l}\text { Russia, Trans-Baikal Territory } 7, \text { Afonina, A5610/4, } \\
\text { (as C. polystratosa, KPABG) }\end{array}$ & KF805869 & KF805902 \\
\hline C. varians & $\begin{array}{l}\text { Russia, Trans-Baikal Territory 8, Afonina, A6010b, (as C. po- } \\
\text { lystratosa, KPABG) }\end{array}$ & KF805868 & KF805901 \\
\hline $\begin{array}{l}\text { Cylindrocolea recurvifolia } \\
\text { (Steph.) Inoue }\end{array}$ & $\begin{array}{l}\text { Japan, Kiushu, Exsiccatae Bryophytes of Asia Fasc. } 14 \text { \# } 344 \\
\text { (KPABG) }\end{array}$ & KF805891 & KF805939 \\
\hline $\begin{array}{l}\text { Diplophyllum albicans (L.) } \\
\text { Dumort. }\end{array}$ & $\begin{array}{l}\text { Russia, Republic of Karachaevo-Cherkesia, Konstantinova } \\
\text { \& Savchenko, K446-7-05 (KPABG) }\end{array}$ & EU791773 & EU791659 \\
\hline $\begin{array}{l}\text { Douinia imbricata (M. Howe) } \\
\text { Konstant. \& Vilnet }\end{array}$ & USA, Alaska, Konstantinova, 110-2-92a (KPABG) & EU791770 & EU791658 \\
\hline $\begin{array}{l}\text { Gymnocolea inflata (Huds.) } \\
\text { Dumort. }\end{array}$ & Norway, Spitsbergen, Konstantinova, 118-1-04 (KPABG) & EU791787 & EU791661 \\
\hline $\begin{array}{l}\text { Heterogemma capitata } \\
\text { (Hook.) Konstant. \& Vilnet }\end{array}$ & $\begin{array}{l}\text { Russia, Nizhny Novgorod Province, Konstantinova, 132-03 } \\
\text { (KPABG) }\end{array}$ & DQ875119 & DQ875080 \\
\hline $\begin{array}{l}\text { Isopaches decolorans } \\
\text { (Limpr.) H. Buch }\end{array}$ & $\begin{array}{l}\text { Russia, Republic of Karachaevo-Cherkesia, } \\
\text { Konstantinova \& Savchenko, K464-3-05 (KPABG) }\end{array}$ & EU791798 & EU791680 \\
\hline $\begin{array}{l}\text { Lophozia ascendens } \\
\text { (Warnst.) R. M. Schust. }\end{array}$ & $\begin{array}{l}\text { Russia, Republic of Buryatia, Konstantinova \& Savchenko, } \\
\text { 109-3-01 (KPABG) }\end{array}$ & DQ875089 & DQ875054 \\
\hline $\begin{array}{l}\text { Lophoziopsis excisa (Dicks.) } \\
\text { Konstant. \& Vilnet }\end{array}$ & Norway, Spitsbergen, Konstantinova, K-21-2-05 (KPABG) & DQ875093 & DQ875058 \\
\hline
\end{tabular}


Table 1. Continued.

\begin{tabular}{|c|c|c|c|}
\hline \multirow{2}{*}{ Taxon name } & \multirow{2}{*}{ Voucher specimens } & \multicolumn{2}{|c|}{ GenBank accession number } \\
\hline & & ITS1-2 & trnL-F \\
\hline $\begin{array}{l}\text { Neoorthocaulis attenuatus } \\
\text { (Mart.) L. Söderstr., De Roo } \\
\text { \& Hedd. }\end{array}$ & $\begin{array}{l}\text { Russia, Sakhalin Province, Harpel \& Cherdantseva, } 105728 \\
\text { (KPABG) }\end{array}$ & EU722343 & EU727538 \\
\hline $\begin{array}{l}\text { Odontoschisma denudatum } \\
\text { (Nees) Dumort. }\end{array}$ & Czech Republic, Konstantinova, 103546 (KPABG) & JX629877 & JX630008 \\
\hline $\begin{array}{l}\text { O. fluitans (Nees) L. Söderstr. } \\
\text { \& Váňa }\end{array}$ & Russia, Kamchatskaya Province, Bakalin, K-13-7-03 (KPABG) & JX629885 & JX630012 \\
\hline $\begin{array}{l}\text { Protolophozia elongata } \\
\text { (Steph.) Schljakov }\end{array}$ & Russia, Murmansk Province, Bakalin, 3-1-02 (KPABG) & DQ875116 & DQ875078 \\
\hline $\begin{array}{l}\text { Pseudolophozia debiliformis } \\
\text { (R. M. Schust. \& Damsh.) } \\
\text { Konstant. \& Vilnet }\end{array}$ & $\begin{array}{l}\text { Russia, Republic of Karachaevo-Cherkessia, Konstantinova } \\
\text { \& Savchenko K510-1-05 (KPABG) }\end{array}$ & EF065692 & EF065685 \\
\hline $\begin{array}{l}\text { Pseudotritomaria hete- } \\
\text { rophylla (R. M. Schust.) } \\
\text { Konstant. \& Vilnet }\end{array}$ & Russia, Krasnoyarskiy Territory, Fedosov, 107960 (KPABG) & EU791806 & EU791687 \\
\hline $\begin{array}{l}\text { Saccobasis polymorpha } \\
\text { (R. M. Schust.) Schljakov }\end{array}$ & $\begin{array}{l}\text { Russia, Murmansk Province, Konstantinova, 21-3b-96 } \\
\text { (KPABG) }\end{array}$ & EU791807 & EU791688 \\
\hline Scapania apiculata Spruce & $\begin{array}{l}\text { Russia, Republic of Buryatia, Konstantinova, } \\
\text { Hepaticae Rossica Exsiccatae № } 49 \text { (KPABG) }\end{array}$ & EU791741 & EU791633 \\
\hline $\begin{array}{l}\text { Schljakovia kunzeana (Hue- } \\
\text { bener) Konstant. \& Vilnet }\end{array}$ & Russia, Murmansk Province, Konstantinova, 181-02 (KPABG) & EU722349 & EU727544 \\
\hline $\begin{array}{l}\text { Sphenolobus minutus } \\
\text { (Schreb.) Berggr. }\end{array}$ & Norway, Spitsbergen, Konstantinova, 68-1-06 (KPABG) & EU791789 & EU791667 \\
\hline $\begin{array}{l}\text { Tetralophozia filiformis } \\
\text { (Steph.) Urmi }\end{array}$ & $\begin{array}{l}\text { Russia, Republic of Buryatia, Konstantinova \& Savchenko, } \\
\text { 13-24-01 (KPABG) }\end{array}$ & EU791792 & EU791669 \\
\hline $\begin{array}{l}\text { Tritomaria exsectiformis } \\
\text { (Breidl.) Loeske }\end{array}$ & $\begin{array}{l}\text { Russia, Republic of Buryatia, Konstantinova, 83-4-01 } \\
\text { (KPABG) }\end{array}$ & EU791801 & EU791683 \\
\hline
\end{tabular}

than to Cephaloziella. Specifically, we contrasted the hypothesis that the new species and Anastrophyllaceae + Scapaniaceae form a monophyletic group (M1) with the hypothesis that they do not form a monophyletic group (M2). In order to do this, the ratio of the marginal likelihoods of the models M1 and M2, the Bayes factor, was computed.

The logarithm of the Bayes factor is the difference in the logarithms of the marginal model likelihoods (Kass \& Raftery 1995). A rough estimate of the marginal model likelihoods can be obtained as a harmonic mean of the likelihood values of the MCMC samples (Newton \& Raftery 1994). MrBayes 3.2.1 provides that method for estimating the logarithm of the marginal model likelihoods (Ronquist et al. 2011). The harmonic mean of the likelihood values of the MCMC samples is the logarithm of the marginal model likelihood (Ronquist et al. 2011).

To test the hypotheses, a hard constraint (M1) and a negative constraint (M2) were specified. In the step of the hard constraint, the constrained tree was defined wherein Cephaloziella konstantinovae was forced to belong to clade Anastrophyllaceae + Scapaniaceae.
It allowed us to force a partition to always be present in the sampled trees. The harmonic mean from the MCMC-based search was recorded under M1. In the step of the negative constraint, the constrained tree was defined wherein Cephaloziella konstantinovae was forced not to belong to Anastrophyllaceae + Scapaniaceae. It allow sampling across all trees that do not contain the specified partition. The harmonic mean from the MCMC-based search was recorded under M2. The difference between harmonic means from both runs, the logarithm of the Bayes factor, was calculated. The corresponding interpretation was found in the table of Kass and Raftery (1995). To use this table, twice the difference in the harmonic means was calculated (Ronquist et al. 2011).

\section{RESULTS}

Nuclear ribosomal ITS sequences and chloroplast DNA trnL-F sequences were newly generated for 31 specimens. The ITS1-2+trnL-F alignment 


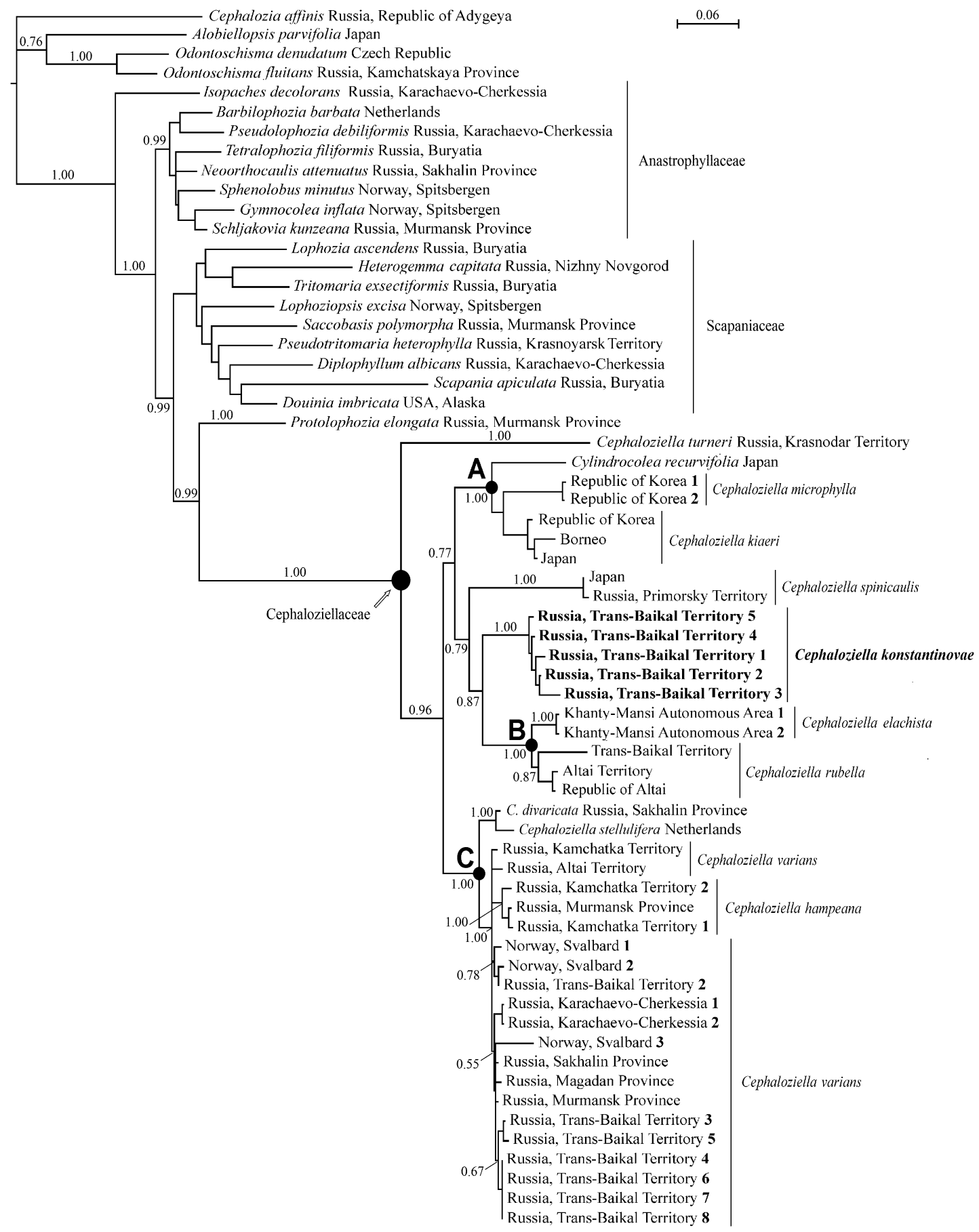

Fig. 1. Phylogenetic tree for suborder Cephaloziineae based on combined ITS1-2+trnL-F nucleotide sequence data from 63 specimens constructed by Bayesian methodology. Bayesian posterior probabilities greater than 0.50 are indicated. 


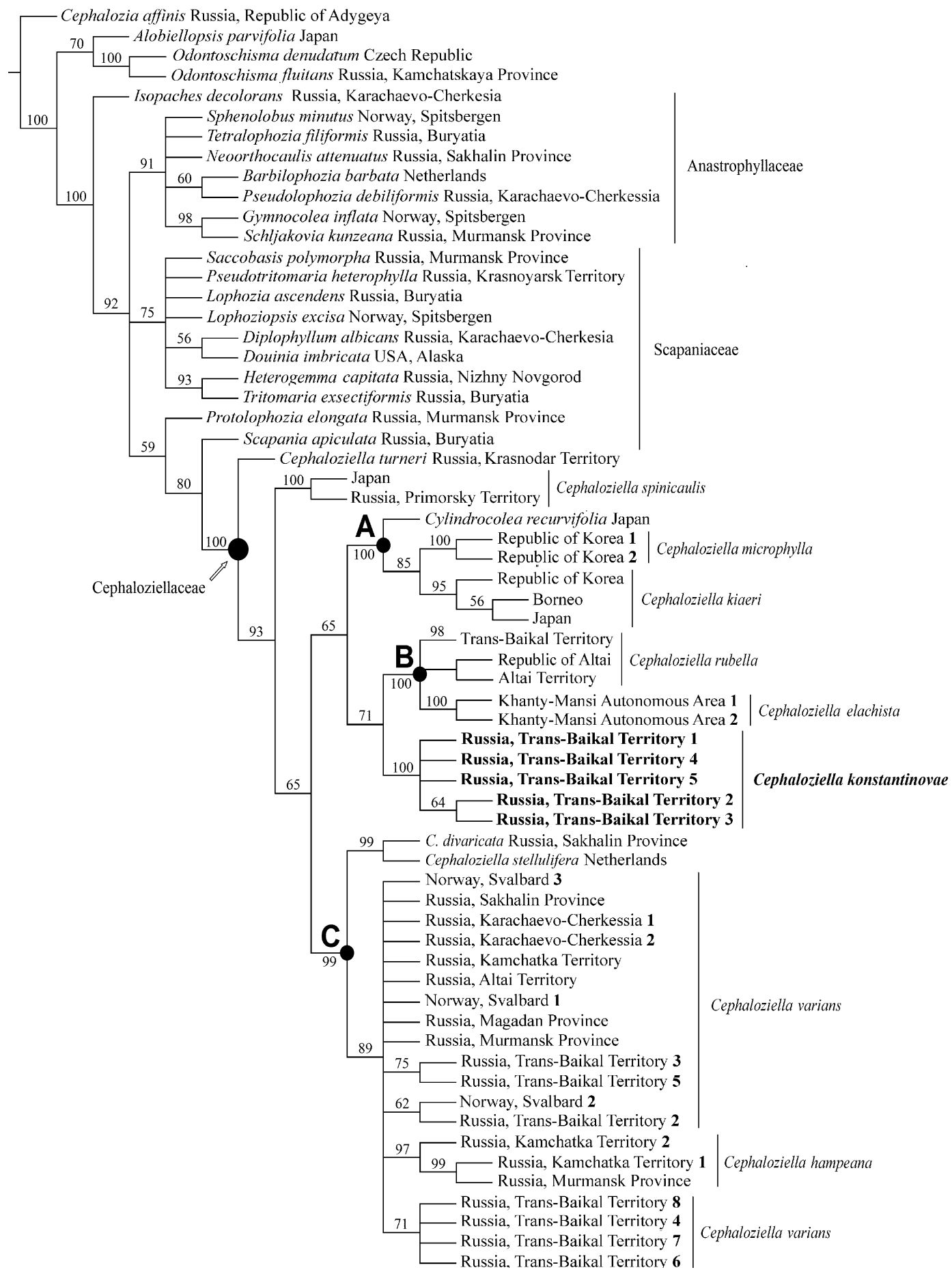

Fig. 2. Phylogenetic tree for suborder Cephaloziineae based on combined ITS1-2+trnL-F nucleotide sequence data from 63 specimens constructed by maximum parsimony method. Jackknife support values greater than $50 \%$ are indicated. 
(63 specimens) included 1822 character sites, among them 852 constant positions; 296 were variable and 674 parsimony-informative.

Arithmetic means of log likelihoods in the BA analysis in both runs sampled were $-15,143.52$ and $-15,145.63$. The Bayes factor calculation revealed the harmonic mean estimate for model M2 as $-15,205.20$ in $\log$ units. For model M1 it is $-15,383.98$ in log units, which is $c a 179 \log$ units worse than the previous model. Twice the difference between the harmonic means is $358 \log$ units. A log difference above 5 is considered to be very strong evidence in favor of the better model (Kass $\&$ Raftery 1995). Thus, the harmonic mean estimator gives very strong evidence in favor of $\mathrm{Ce}$ phaloziella konstantinovae being distant from both Anastrophyllaceae and Scapaniaceae.

The Bayesian and the parsimony topologies were largely similar (Figs $1 \& 2$ ). The majority of Cephaloziella accessions are found in three clades - A, B and C - which are stable in both BA and MP trees but differently supported in the calculations. Clade A ( $\mathrm{JS}=100 \%, \mathrm{PP}=1.00)$ includes Cephaloziella kiaeri (Austin) Douin, C. microphylla (Steph.) Douin and Cylindrocolea recurvifolia (Steph.) Inoue.

Clade B (JS $=100 \%$ in MP, $\mathrm{PP}=1.00$ in $\mathrm{BA})$ of BA and MP topologies contains C. elachista (J. B. Jack) Schiffn. and C. rubella (Nees) Warnst. The specimen 'Trans-Baikal Territory' of C. rubella forms a long branch in the Bayesian tree and a separate subclade in the MP tree. The well-supported ( $\mathrm{JS}=100 \%, \mathrm{PP}=1.00)$ subclade including two specimens of Cephaloziella spinicaulis Douin is placed differently in BA and MP topologies.

Five specimens of the new species $C$. konstantinovae from Trans-Baikal Territory form a distinct subclade $(\mathrm{JS}=100 \%, \mathrm{PP}=1.00)$ resolved as sister to clade B in BA and MP. Clade C (JS $=99 \%$, $\mathrm{PP}=1.00)$ includes specimens of $C$. divaricata (Sm.) Schiffn., C. hampeana (Nees) Schiffn. ex Loeske, C. stellulifera (Taylor) Schiffn. and C. varians (Gottsche) Steph. The species C. turneri (Hook.) Müll. Frib. forms a sister relationship with all other Cephaloziellaceae elements in the BA and MP trees.

\section{Discussion}

MORPHOLOGICAL SIMILARITY OF CEPHALOZIELLA KONSTANTINOVAE WITH THE TAXA OF CEPHALOZIINEAE

In the present study the narrow concept of Cephaloziellaceae of Schuster (2002) rather than the wide concept of Söderström et al. (2016) is accepted; however, we take the proposals of CrandallStotler et al. (2009), Gradstein et al. (2014) and Patzak et al. (2016) into account. We consider the genera Allisoniella E. A. Hodgs. (incl. Protomarsupella R. M. Schust.), Amphicephalozia R. M. Schust., Cephalojonesia Grolle, Cephalomitrion R. M. Schust., Cephaloziella, Cephaloziopsis (Spruce) Schiffn., Chonecolea Grolle, Cylindrocolea R. M. Schust., Gymnocoleopsis (R. M. Schust.) R. M. Schust., Kymatocalyx Herzog (incl. Stenorrhipis Herzog) and Phycolepidozia R. M. Schust. as elements of Cephaloziellaceae s.str.

Although the present analyses did not resolve deeper nodes of Cephaloziella, it is clear that our new species is nested within this genus.

Being first recognized from the Trans-Baikal Territory in 2009, the new species was found subsequently in the Republic of Buryatia, southern Siberia, in Primorsky Territory, the Russian Far East, and the Republic of Mongolia. Due to the presence of well-developed underleaves and multicellular outgrowths on the abaxial leaf face, the sterile specimens of this species were initially identified as Cephaloziella divaricata var. asperifolia (Taylor) Damsh. or C. byssacea var. asperifolia Macvicar (in herb. VBGI) and published as $C$. aspericaulis Jørg. or C. divaricata var. asperifolia (Taylor) Damsh. for the TransBaikal Territory, Russia (Konstantinova \& Afonina 2009; Afonina et al. 2012; Czernyadjeva et al. 2013) or C. microphylla (Steph.) Douin for Tuv Aimag of Mongolia (Tsegmed \& Bai 2013). The senior author's collections contain fertile plants with mature androecia, perianthia and sphorophytes. These plants' characteristics are as follows: ( $i$ ) female bracts entirely free from each other and from bracteole, (ii) perianth campanulate, (iii) cells of perianth mouth rounded-rectangular to subquadrate, $(i v)$ capsule spherical, $(v)$ seta with 8-10 
+ 4-6-seriate morphology, and (vi) elaters with 1-2 spiral bands. According to Schuster (2002), none of the genera of Cephaloziellaceae have this combination of character states of the reproductive structures. In Chonecolea, which is considered an element of Cephaloziellaceae by Patzak et al. (2016), all of those characteristics are present, but the spore surface in Chonecolea is reticulate, whereas in Cephaloziella konstantinovae as well as other Cephaloziellaceae (except Cylindrocolea reticulata) the spore surface is finely granulate, papillose or verruculose.

In seta morphology, Cephaloziella konstantinovae resembles the genera Allisoniella, Amphicephalozia, Cephalomitrion and Chonecolea of Cephaloziellaceae s.str. In Cephaloziella konstantinovae the seta is $8-10+4-6$-seriate, whereas in the monospecific genus Cephalomitrion the seta is $8+4$-seriate (Schuster 2002), in Chonecolea it varies from $4+5$-seriate to $8+4$-seriate (Schuster 1980; Jones 1985), and in Amphicephalozia amplexicaulis R. M. Schust. the seta has 8-9 outer $+4-6$ smaller internal cells (Schuster 2002). The genus Allisoniella has a seta with 8 outer $+(3) 4$ to $12-14$ smaller inner cells (Schuster 2002); however, Allisoniella subbipartita (C. Massal.) R. M. Schust. \& J. J. Engel is illustrated to have a seta with 9 outer $+8-13$ inner cells (Schuster 2002: Fig. 247: 7 \& 8). In contrast, the genera Cylindrocolea, Kymatocalyx, Cephaloziopsis and Phycolepidozia of Cephaloziellaceae s.str. have $4+4$-seriate setae; Cephalojonesia and Cephaloziella have 4(5) +4(5)-seriate and 4(5-6) $+4(5)$-seriate setae, respectively (Grolle \& Vanden Bergen 1970; Schuster 2002).

It should be noted that the 8-10 outer seta cells of Cephaloziella konstantinovae do not occur in other members of Cephaloziellaceae s.str. In this character the new species is similar to some elements of Lophoziaceae sensu Schuster (1969), where the seta consists of numerous cell rows or is reduced to (2-3)4 inner and (6-7)8 outer rows in some taxa (Schuster 1969: 219). According to Schuster (2002) this seta anatomy occurs in Lophozia badensis (Gottsche) Schiffn. (nowadays considered as Mesoptychia badensis (Gottsche) L. Söderstr. \& Váňa of Jungermanni- aceae) and Anastrophyllum hellerianum (Nees ex Lindenb.) R. M. Schust. [syn. Crossocalyx hellerianus (Nees ex Lindenb.) Meyl.], but it is never fixed at the $8+4$ state in these taxa (Schuster 2002).

On the other hand, in Lophozioideae sensu Schuster (1969) the area of one inner cell of the seta (in cross section) approximates that of one outer cell of the seta (Schuster 1969: Fig. 163: 2, Fig. 235: 7-10, Fig. 242: 2, Fig. 244: 4). In all species of Cephaloziellaceae s.str., especially in Cephalojonesia, Cephaloziella, Cephaloziopsis, Cylindrocolea, Kymatocalyx and Phycolepidozia, the inner cells of the seta are reduced in size, so that the area of inner cells (in cross section) does at best reach the size of one outer cell (Douin 1908, 1920; Grolle \& Vanden Bergen 1970; Schuster 2002). This character is also observed in Cephaloziella konstantinovae where the collective area of inner seta cells (in cross section) is almost equal to that of one outer seta cell (Figs $25 \& 27$ ).

Within Lophozioideae, Gymnocoleopsis capensis (S. W. Arnell) R. M. Schust. has a seta morphology of the $8+4$-type, but the inner cells (in cross section) are reduced in size (Arnell 1963; Schuster 2002). On the other hand, a close affinity between Gymnocoleopsis and Cephaloziella was shown in a molecular phylogenetic study of Lophoziaceae (De Roo et al. 2007), and the genus Gymnocoleopsis is now placed within Cephaloziellaceae s.str. (Crandall-Stotler et al. 2009; Váňa et al. 2013).

The genera Protolophozia (R. M. Schust.) Schljakov and Pseudocephaloziella R. M. Schust. of the former Lophoziaceae resemble Cephaloziella konstantinovae in the absence of nodular thickenings on the cell walls and the presence of well-developed underleaves. However, the phylogenetic relationships of Pseudocephaloziella remain unclear because the sporophyte characters are unknown and nucleotide sequence data are not available. The genus Protolophozia differs from Cephaloziella konstantinovae in seta morphology. According to Schuster (1988: 63, Fig. 5: 10), the seta in Protolophozia elongata (Steph.) Schljakov consists of 17 outer and 20 inner cells that do not differ in size. Moreover, the phylogenetic position of Protolophozia is not yet established. Schuster 
(2002) considers Protolophozia (incl. P. elongata) to be a subgenus within the genus Lophozia. Heinrichs et al. (2005) proposed to merge Lophoziaceae into Scapaniaceae; in Konstantinova et al. (2009), Protolophozia was placed within Scapaniaceae s.str. (excl. genera later assigned to Anastrophyllaceae). Vilnet et al. (2012) found inconsistent positions of Protolophozia elongata in a series of phylogenetic analyses; however, Váňa et al. (2013) proposed to include Protolophozia in Cephaloziellaceae. In the obtained phylogenetic trees (Figs 1 \& 2), Protolophozia elongata is related to the clade of Anastrophyllaceae + Scapaniaceae rather than to Cephaloziellaceae.

The bracts and bracteoles are entirely free in Cephaloziella konstantinovae, Amphicephalozia, Cephalojonesia, Cephaloziopsis and Chonecolea, but more or less connate at the base in Allisoniella, Cephaloziella, Cephalomitrion, Cylindrocolea, $\mathrm{Ky}$ matocalyx and Phycolepidozia.

For the abovementioned reasons, the seta structure as well as the shape of bracts and bracteole and the degree of their connection probably are not sufficient to delimitate genera of Cephaloziellaceae s.str. It may be that vegetative characters, particularly the branching mode and the presence/ absence of underleaves, are of greater taxonomic importance.

The campanulate perianth and the subisodiametric cells of the perianth mouth of Cephaloziella konstantinovae resemble the character state of Cephalojonesia incuba Grolle \& Vanden Bergen, Cephaloziopsis exigua (Inoue) Inoue \& R. M. Schust (syn. Metacephalozia exigua Inoue; Inoue 1973), and the species of Chonecolea and Cylindrocolea subg. Cylindroscyphus (Douin) R. M. Schust., namely Cylindrocolea atroviridis (Sim) Váňa, C. reticulata Udar \& Ad. Kumar and $C$. rhizantha (Mont.) R. M. Schust. However, the spherical capsule and 1-2-spiralled elaters of Cephaloziella konstantinovae otherwise occur only in Chonecolea species and Cylindrocolea reticulata.

The combination of characters of Cephaloziella konstantinovae is unusual for the family Cephaloziellaceae s.str. Some of these characters are presented in isolated species of oligospecific genera and subgenera - Allisoniella, Amphicephalozia, Cephalojonesia, Cephaloziopsis, Cylindrocolea subg. Cylindroscyphus - but have been found collectively (excl. spore surface) only in Chonecolea. Furthermore, the type of reproductive structures found in Cephaloziella konstantinovae is unknown in other species of the genus Cephaloziella.

Cephaloziella konstantinovae lacks ventral branching but has Frullania-type terminal branches. This branching mode is untypical for Cephaloziellaceae s.str. but occurs in Lophoziaceae sensu Schuster (1969). However, Schuster (1988: 189) points to the presence of Frullania-type branches in Cephaloziella byssacea (Roth) Warnst. and other members of Cephaloziella (Schuster 2002: 107). Fulford (1976) describes Frullaniatype branches in Cylindrocolea and Cephaloziella subtilis (Lindenb. \& Gottsche) Steph. The shoots of Cephaloziella crispata N. Kitag., C. indica Udar $\&$ Ad. Kumar and C. stellulifera (Taylor) Schiffn. were described as simple or having only a few lateral branches (Kitagawa 1969; Udar \& Kumar 1980; Schuster 1980); also in Cylindrocolea, ventral-intercalary branching may be absent (Schuster 2002: 91).

In stem anatomy Cephaloziella konstantinovae resembles some other members of Cephaloziellaceae s.str., namely all species of Cephaloziopsis, Chonecolea, Cylindrocolea subg. Cylindroscyphus, Cephalojonesia incuba, Cephaloziella crispata and C. stephanii Schiffn. ex Douin.

Cephaloziella konstantinovae differs in some significant characters from species of Lophoziaceae sensu Schuster (1969). Members of the former Lophoziaceae are currently considered to belong to three families: Anastrophyllaceae (Söderström et al. 2010), Scapaniaceae, and Jungermanniaceae s.str. (Hentschel et al. 2007; Crandall-Stotler et al. 2009; Konstantinova et al. 2009; Vilnet et al. 2010). Cephaloziella konstantinovae differs from Anastrophyllaceae by the absence of any thickenings in cell walls, and from Scapaniaceae by the presence of regular well-developed (0.5-0.7 of leaf length) underleaves. The family Jungermanniaceae nowadays includes only the genera Delavayella Steph., Jungermannia L., Eremonotus Pearson, Liochlaena Nees and Mesoptychia 
(Lindb.) A. Evans (Crandall-Stotler et al. 2009; Váňa et al. 2012; Shaw et al. 2015). Members of these genera have large oil-bodies (Damsholt 2002), and fusiform to obovoid perianths with the mouth contracted to a narrow beak. In contrast, Cephaloziella konstantinovae has much smaller oil-bodies and a campanulate perianth with an uncontracted mouth; in other Cephaloziella species the oil-bodies are small as well, and the perianths are somewhat but not strongly contracted to the truncate mouth (Damsholt 2002; Schuster 2002).

\section{PHYLOGENETIC RELATIONSHIPS}

AND MORPHOLOGICAL FEATURES WITHIN

HOLARCTIC CEPHALOZIELLA

Our molecular phylogenies compelled us to reexamine the morphology of the included Cephaloziella accessions and to revise species identifications. Plants initially identified as Cephaloziella arctogena (R. M. Schust.) Konstant. ('Trans-Baikal Territory') with large underleaves on sterile shoots and without gemmae were found in one clade in the Bayesian tree together with plants determined as C. elegans (Heeg) Schiffn. ('Republic of Altai') characterized by purplish and violet pigmentation, broad leaf lobes (up to 9 cells wide), distinct underleaves, the presence of gemmae, and C. rubella ('Altai Territory') with narrow leaf lobes (5-7 cells wide), claret red to violet pigmentation, and small indistinct underleaves on both fertile and gemmiferous shoots. We consider our molecular data to be supportive of a treatment of $C$. arctogena and C. elegans as varieties of C. rubella: $C$. rubella var. arctogena $\mathrm{R}$. M. Schust. and C. rubella var. elegans (Heeg) R. M. Schust. respectively. It should be noted that the specimen 'Trans-Baikal Territory' of $C$. rubella forms a long branch in the Bayesian tree and a separate subclade in the MP tree.

The $C$. rubella clade is resolved as sister to C. elachista in both BA and MP topologies. Cephaloziella elachista is the type of section Schizophyllum (Müll. Frib.) Jørg., and C. rubella is the type of section Rubellae R. M. Schust. Hence, section Rubellae probably should be reduced to a synonym of section Schizophyllum.

The close affinity between Cylindrocolea recurvifolia and other species of Cephaloziella is evident from the presented phylogenetic trees. This species is nested within clade A together with C. kiaeri and C. microphylla, being related to them in several identical nucleotide substitutions as well as unique insertions and deletions in both ITS1-2 and trnL-F. Accordingly, Cylindrocolea recurvifolia should be treated as Cephaloziella recurvifolia (Steph.) S. Hatt. Members of clade A share autoicy and an East Asian origin.

Cephaloziella spinicaulis is resolved within the group of clades A, B, and C. konstantinovae in the Bayesian tree, or a well-supported subclade distant to clades A, B, and C in the MP topology. It resembles species of clade $\mathrm{A}$ in its tendency to form flagelliform shoot apices and frequent axillary postical intercalary branches. However, it is a dioecious species with $(i)$ a disjunctive, probably relictual distribution in East Asia and eastern North America, and (ii) a conspicuously roughened stem with numerous spine-like, simple or bifurcate projections of $1-4$ cells arranged in longitudinal lines.

Cephaloziella turneri is separated from all other Cephaloziellaceae elements in the BA and MP topologies. The remote affinity of $C$. turneri to other congeneric species was also shown in Feldberg et al. (2013). This species produces angulate gemmae, whereas other analyzed species of Cephaloziella have smooth elliptical gemmae.

Cephaloziella varians appears to be a highly variable species that is widely distributed in Russia, especially in the mountains of southern Siberia and the Russian Far East. All studied specimens are identical in trnL-F and have minor differences in ITS sequences. All specimens have irregular and entire (not bifid) underleaves of different sizes. The majority of these specimens consist of sterile plants only, and were thus initially assigned to $C$. divaricata or C. polystratosa (R. M. Schust. \& Damsh.) Konstant. Some autoecious specimens were initially determined as $C$. grimsulana due to having obtuse or rounded leaves and large leaf cells, or as $C$. uncinata and $C$. spinigera due to the presence of elongated, somewhat hooked leaves and small leaf cells.

The 'true' Cephaloziella divaricata seems to be rare in Russia. Only a single specimen from Sakhalin (Bakalin S-24-21-09) is found 
in one clade with the specimen identified earlier as C. stellulifera (Taylor) Schiffn. from the Netherlands (Konstantinova 1e-2-99). The plants of $C$. divaricata from Sakhalin are sterile and have regular well-developed ( $c a$ 0.5 of leaf length) bifid underleaves, whereas the specimen of $C$. stellulifera contains plants bearing only paroecious inflorescences, well-developed bifid underleaves up to 0.7 of leaf length, and large cells at the base of leaf lobes, 17-19 $\mu \mathrm{m}$.

Specimens initially identified as C. uncinata R. M. Schust. ('Kamchatka Territory 1'), C. subdentata Warnst. ('Murmansk Province') and C. hampeana (Nees) Schiffn. ex Loeske ('Kamchatka Territory 2') share largely similar DNA sequences. They were all placed in C. hampeana due to these features: $(i)$ leaf cells $14-16 \mu \mathrm{m}$ wide, (ii) leaf lobes up to 7-8 cells wide at base, (iii) the absence of underleaves, and (iv) strongly connate (up to $2 / 3$ their height) female bracts and bracteoles. The taxonomy of the morphologically similar species $C$. uncinata and $C$. hampeana needs additional study.

Members of clade $\mathrm{C}$ are morphologically heterogeneous yet show only low levels of ITS and trnL-F sequence variation. Follow-up studies need to include more variable marker systems and more extensive sampling.

\section{DESCRIPTION OF THE NEW SPECIES}

Cephaloziella konstantinovae Mamontov \& Vilnet, sp. nov.

Figs 3-29

Diagnosis. The new taxon resembles many other species of Cephaloziella by its large underleaves and multicellular outgrowths on the dorsal leaf face, but differs by unusual characters of the reproductive structures: $(i)$ female bracts and bracteole not connate, (ii) campanulate perianth, (iii) rectangular to subquadrate cells of perianth mouth, (iv) spherical capsule, (v) seta composed of 8-10 outer and 4-6 inner cell rows, and ( $v i)$ elaters with 1-2 spiral bands.

TyPe: RUSSIA, Trans-BaIKal Territory, Khentey-Chikoyskoye Nagor'e Uplands, Sokhondinskiy State Biosphere Reserve, valley of Sokhondo River, $49^{\circ} 30^{\prime} \mathrm{N}$,
111 ${ }^{\circ} 04^{\prime}$ E, 1205 m a.s.1., 23 Aug. 2011, Mamontov 166-7 (HOLOTYPE: KPABG; ISOTYPES: G, LE, MHA, NICH).

Description. Plants delicate, dull green, with red-brown secondary pigmentation mostly on leaf margins, shining in dry condition, ascending to erect (Figs $20 \& 24$ ). Shoots up to $0.6 \mathrm{~mm}$ wide and $5 \mathrm{~mm}$ long. Stems $70-160 \mu \mathrm{m}$ in diameter, 9-12 cells across. Cortical and medullary region indistinct in cross section, cells thinwalled throughout (Figs 4 \& 13), peripheral cells somewhat larger, 10-16(-19) $\mu \mathrm{m}$, central cells 10 $13(-17) \mu \mathrm{m}$. Cortical cells of the stem thin-walled, inflated, mostly rounded-rectangular in view from above, 18-35 $\mu \mathrm{m}$ long, 11-19 $\mu \mathrm{m}$ wide. Branching abundant, terminal and lateral-intercalary (Figs 10, 20, 21, 24), without ventral-intercalary branches and subfloral innovations. Rhizoids small, hyaline, indistinct. Leaves succubous, distant, almost transversely inserted, concave-conduplicate, with reflexed margins, subquadrate to oblate, or obtrapezoidal, 200-260 $\mu \mathrm{m}$ long, 280-410 $\mu \mathrm{m}$ wide, asymmetrical, divided $0.4-0.8$ of the length into two divergent lobes 5-20 cells wide at base, sometimes trilobed (Fig. 3), armed on abaxial face with outgrowths similar to marginal teeth, 1-4 cells long and 1-3 cells wide at base, (Figs $3,7,8,10,16,18,19-22,24)$. Leaf lobes unequal or rarely nearly equal-sized, dorsal lobe usually smaller (shorter and more narrow) than ventral one, apex acute to obtuse, or rounded, sinus acute to obtuse. Leaf margins mostly irregularly crenulate by convex and projected cells, usually with 1-3 irregular, obtuse or rounded teeth 1-4 cells long and 1-7 cells wide at base, unistratose throughout (Figs 3, 8, 22, 23). Leaf cells rectangular to rounded, uniformly thin-walled, inflated, 11.5-16(-20) $\mu \mathrm{m}$ wide at base of lobes. Oilbodies 3-7 per cell, 1-3 × 1-2.3 $\mu \mathrm{m}$, spheroidal to ellipsoid, smooth (Fig. 11). Underleaves mostly 0.5-0.7 of leaf length, 130-180(-250) $\mu \mathrm{m}$ long and $65-130(-180) \mu \mathrm{m}$ wide, 4-6(-12) cells wide, entire or with lateral teeth or lobes (Figs 20, 22, 26), margins crenulate by convex, projecting cells. Gemmae not observed.

Autoecious, but pseudodioecious due to the fragility of the plants. Androecia on main shoots 


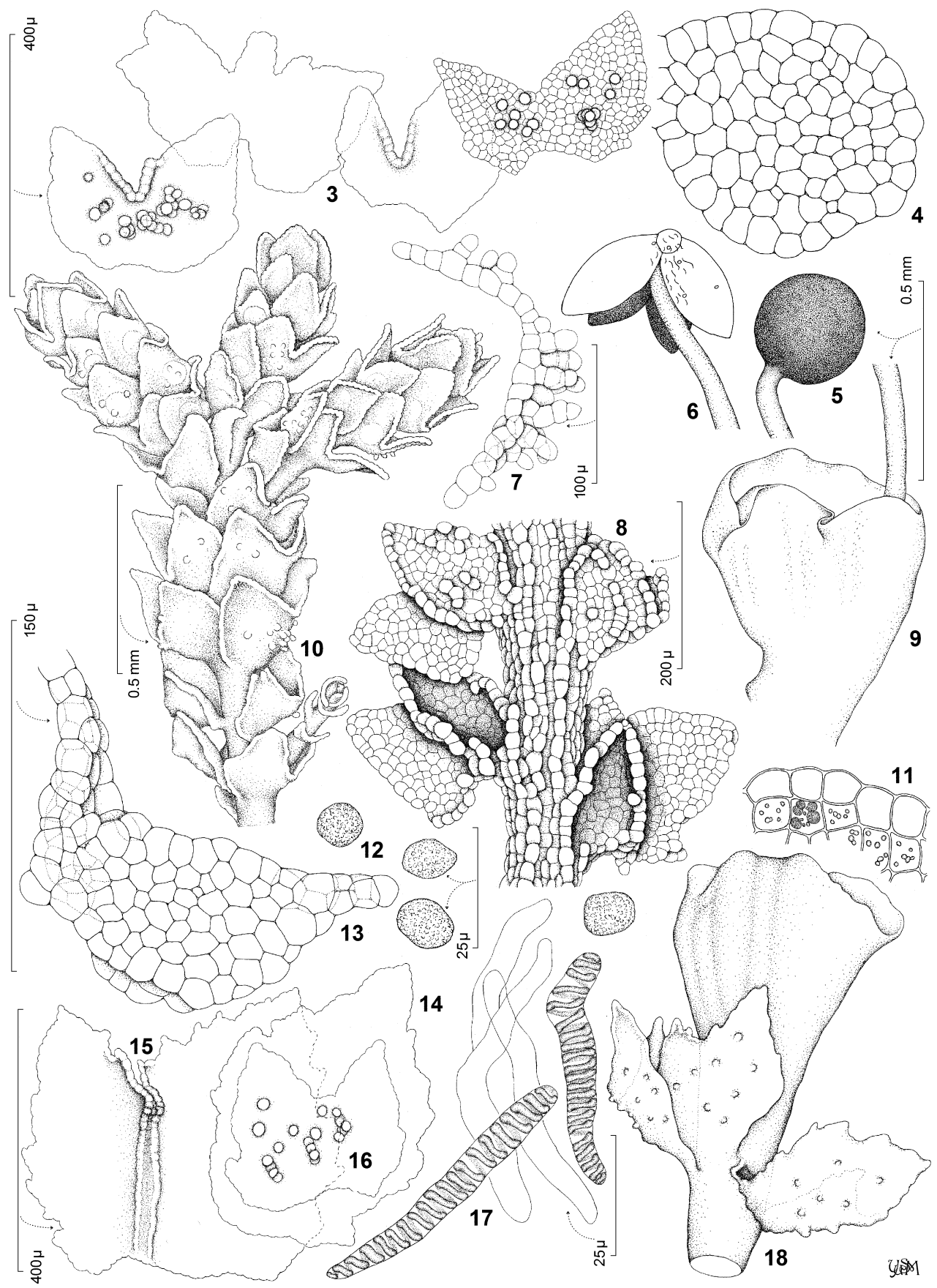

Figs 3-18. Cephaloziella konstantinovae Mamontov \& Vilnet, sp. nov. 3 \& 16 - leaves, abaxial face, 4 \& 13 - stem cross sections, 5 - closed capsule, 6 - opened capsule, 7 - cross section of leaf base, 8 - part of shoot, dorsal aspect, $9 \& 18$ - perianths, 10 - cluster of male branches, 11 - cells of perianth mouth with oil-bodies (light) and chloroplasts (black) indicated, 12 - spores, 14 - female bracteole, 15 - female bract, 17 - elaters. 3, 4, 7, 8, 10, 11, 13-16 from Mamontov 166-7 (KPABG); 6, 9, 17 from Mamontov 169-5 (KPABG); 5, 12, 18 from Afonina 6010 (KPABG). 
and on clusters of short terminal branches (Figs $10 \& 21$ ), bracts usually in 3-4 pairs, strongly concave, with reflexed margins, similar in size with leaves. Antheridium single per bract, body globose to subglobose, stalk uniseriate. Gynoecia terminal on main shoot or on short branches. Female bracts (Figs $15 \& 28$ ) in one pair, larger than leaves, up to $450 \mu \mathrm{m}$ long and $500 \mu \mathrm{m}$ wide, entirely free from each other, not to slightly saccate, margins dentate by large irregular multicellular teeth $1-5$ cells high, bilobed to $1 / 3$ of their length. Female bracteole (Fig. 14) 430-470 $\mu \mathrm{m}$ long and 300-350 $\mu \mathrm{m}$ wide, with acute to obtuse apex, bilobed less than $1 / 3$ of length, or unlobed, entirely free from bracts, sometimes absent. Perianth $0.7-1.2 \mathrm{~mm}$ long, up to $0.6 \mathrm{~mm}$ wide, usually campanulate, slightly plicate near apex, longly exserted beyond bracts, mouth wide and wavy, truncate (Figs 9, 18, 28). Perianth surface usually covered by outgrowths 1-2 cells long, 1-2 cells wide at base, similar to outgrowths originated on dorsal leaf surface (Figs 28 \& 29); marginal cells of perianth mouth roundedrectangular to subquadrate, $11-15 \times 11-18 \mu \mathrm{m}$, thin-walled throughout, convex (Fig. 11). Seta $0.4-0.8 \mathrm{~cm}$ long, with $8-10$ outer and 4-6 inner cells in cross section; cross-section area of an outer cell varies in the range of $402-1060 \mu \mathrm{m}^{2}$, and the collective cross-section area of inner cells varies from 405 to $630 \mu \mathrm{m}^{2}$ (Figs $25 \& 27$ ). Capsule spherical, dark brown, ca 250-300 $\mu \mathrm{m}$ in diameter (Figs $5 \& 6$ ). Spores light brown, rounded to elliptical, $8.8-12.5 \times 8.2-11.5 \mu \mathrm{m}$, verruculose (Fig. 12). Elaters $4.7-7.5 \mu \mathrm{m}$ in diameter, up to $65 \mu \mathrm{m}$ long, with 1-2 spiral bands (Fig. 17).

ETYMology. The species is named in honor of Prof. Dr. Nadezhda A. Konstantinova, eminent Russian hepaticologist.

Distribution. In Siberia, Cephaloziella konstantinovae is common in low mountain areas in the south of the Republic of Buryatia and Trans-Baikal Territory, and possibly common in the north of Mongolia (Bulgan and Tuv Provinces), but becomes more rare towards the north. It was collected sporadically on the Barguzin and South Muya ranges in the north of Buryatia, and on Kodar Range in the north of Trans-Baikal
Territory, but was not found north of $57^{\circ} \mathrm{N}$. In Primorye Territory, the Russian Far East, C. konstantinovae was collected only once.

Ecology. In Siberia, C. konstantinovae occurs in low mountain steppe communities and forests dominated by Larix dahurica Turcz. and L. sibirica Ledeb., but was not found in mountain forests where Pinus pumila (Pall.) Regel occurs. It grows in pure dense patches on soil in rock niches or on thin soil overlying vertical rock surfaces in partial shade, and also as an admixture to other saxicolous hepatics, especially of the genus Frullania Raddi. The elevation range in Trans-Baikal Territory and the Republic of Buryatia ( $\left.c a 49-56^{\circ} \mathrm{N}\right)$ is $c a 500$ $1600 \mathrm{~m}$ a.s.l. However, in Tuv Aimag, in northern Mongolia, it was collected at $1840 \mathrm{~m}$ a.s.l. (Tsegmed \& Bai 2013, as Cephaloziella microphylla). The liverworts most commonly associated with C. konstantinovae in all types of habitats were Frullania muscicola Steph., F. inflata Gottsche, F. bolanderi Austin and F. parvistipula Steph. Also, Metzgeria pubescens (Schrank) Raddi, Barbilophozia barbata (Schmidel ex Schreb.) Loeske, Frullania davurica Hampe, Lophoziopsis excisa (Dicks.) Konstant. \& Vilnet, Metzgeria furcata (L.) Corda and $M$. temperata Kuwah. were collected together with $C$. konstantinovae on rocks in forests, whereas Clevea nana (Shimizu \& S. Hatt.) Borovich. \& Bakalin, Reboulia hemisphaerica (L.) Raddi and Targionia hypophylla L. were associated with Cephaloziella konstantinovae mostly on rocky steppe slopes along trails and watercourses. In Primorye Territory, C. konstantinovae was found on cliff outliers in broadleaved forest on a west-facing mountain slope at ca $280 \mathrm{~m}$ a.s.l., associated with Frullania muscicola and Acrolejeunea sandvicensis (Gottsche) J. Wang \& Gradst.

OTHER SPECIMENS EXAMINED (PARATYPES). RUSSIA: Trans-Baikal Territory: Khentey-Chikoyskoye Nagor'e Uplands, upper of Bukukun River, 1463 m alt., $49^{\circ} 37^{\prime} \mathrm{N}, 111^{\circ} 00^{\prime} \mathrm{E}, 24$ July 2007 , Afonina $04808-8$ (LE); same uplands, valley of Ende River, $1184 \mathrm{~m}$ alt., $49^{\circ} 26^{\prime} \mathrm{N}, 110^{\circ} 51^{\prime} \mathrm{E}, 11$ July 2010 , Afonina $1810-1$ (MHA); same place, $1161 \mathrm{~m}$ alt., 15 July 2010, Afonina 2910-2 (G), 2910-4 (NICH), 2910-6 (JE), 2910-7 (VBGI), 2910-8 (KPABG); same place, $1161 \mathrm{~m}$ alt., $49^{\circ} 27^{\prime} \mathrm{N}, 110^{\circ} 50^{\prime} \mathrm{E}, 15$ July 2010, Afonina $3010-4$ (G); 


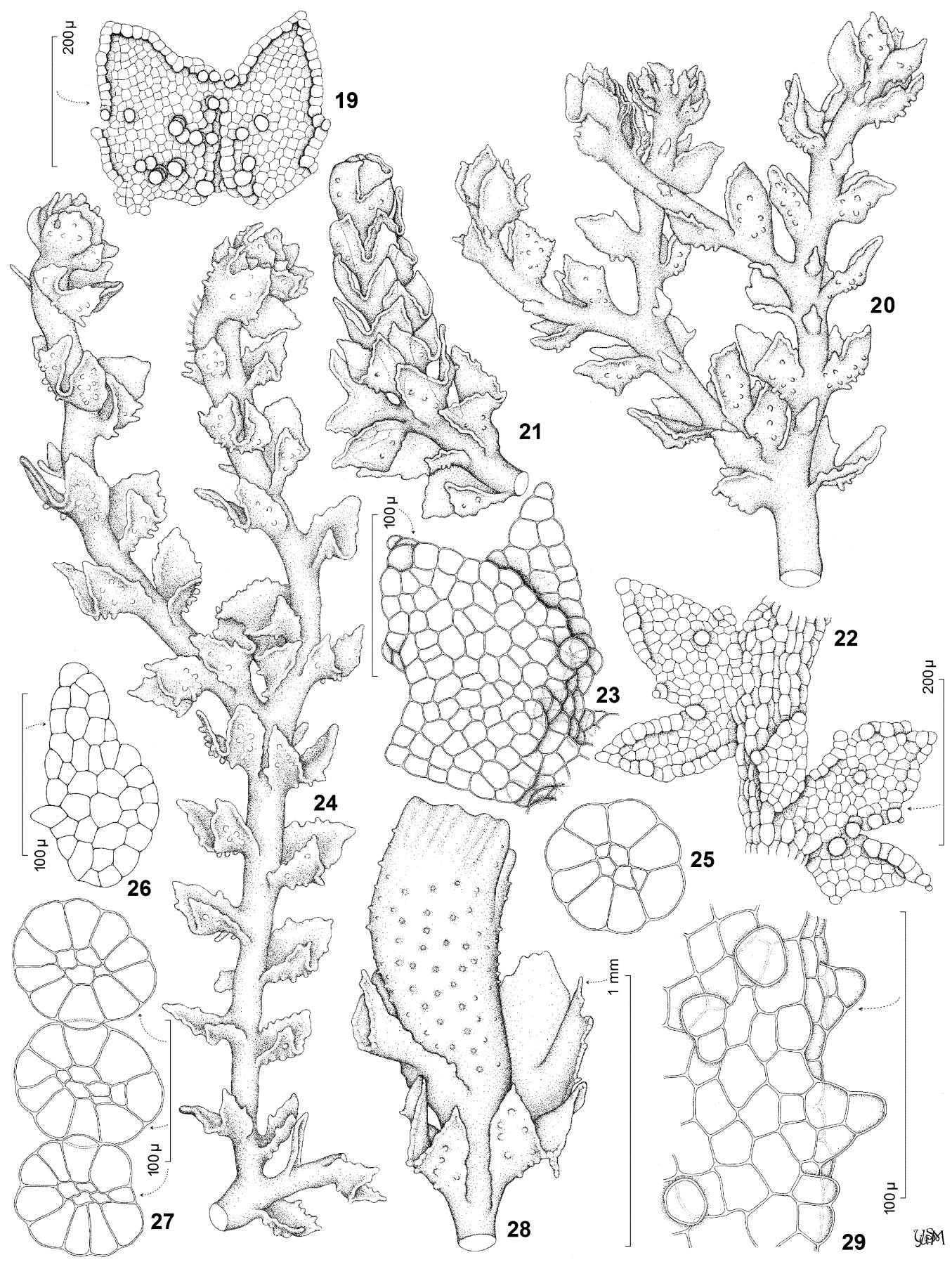

Figs 19-29. Cephaloziella konstantinovae Mamontov \& Vilnet, sp. nov. 19 \& 23 - leaves, abaxial face, 20 - habit, ventral aspect, 21 - male branch, 22 - part of shoot, ventral aspect, 24 - habit, dorsal aspect, 25 \& 27 - cross sections of seta, 26 enlarged underleaf, 28 - perianth, 29 - perianth surface. 19, 22, 23 from Mamontov 166-7 (KPABG); 20, 21, 24, 26-29 from Afonina 6010 (KPABG). 
same place, $1162 \mathrm{~m}$ alt., $49^{\circ} 26^{\prime} \mathrm{N}, 110^{\circ} 51^{\prime} \mathrm{E}, 24$ Aug. 2011, Mamontov 169-5 (KPABG), 169-11 (MO), 1735-2 (G), 178-13-1 (E), 178-8-1 (NICH); KhenteyChikoyskoye Nagor'e Uplands, valley of Ende River, lower reaches of Khukhje-Bajtsa Brook, $1214 \mathrm{~m}$ alt., $49^{\circ} 27^{\prime} \mathrm{N}, 110^{\circ} 52^{\prime} \mathrm{E}, 27$ Aug. 2011, Mamontov 1824-2 (KPABG); same uplands, valley of Agutsa River, $1164 \mathrm{~m}$ alt., $49^{\circ} 38^{\prime} \mathrm{N}, 111^{\circ} 27^{\prime} \mathrm{E}, 17$ July 2010 , Afonina 3410-1 (LE), 3410-2 (KPABG); same uplands, valley of Agutsa River, $1399 \mathrm{~m}$ alt., $49^{\circ} 40^{\prime} \mathrm{N}, 111^{\circ} 26^{\prime} \mathrm{E}, 22$ July 2010, Afonina 5510-3 (NICH), 5510-4 (LE); same place, $1300 \mathrm{~m}$ alt., $49^{\circ} 40^{\prime} \mathrm{N}, 111^{\circ} 26^{\prime} \mathrm{E}, 23$ July 2010 , Afonina 6010-1 (G, KPABG, MHA), Afonina 6010-5 (LE); same uplands, valley of Ingoda River, $1332 \mathrm{~m}$ alt., $49^{\circ} 56^{\prime}$ N., $111^{\circ} 10^{\prime}$ E., 17 July 2013, Mamontov 3721-1 (NICH); same uplands, Khapcheranginskiy Range, valley of Tyrin River, $1078 \mathrm{~m}$ alt., $49^{\circ} 05^{\prime} \mathrm{N}, 112^{\circ} 20^{\prime} \mathrm{E}$, 29 July 2005, Afonina 6805-1 (KPABG); same uplands, near Kyra settlement, valley of Kyra River, 890 m alt., $49^{\circ} 33^{\prime} \mathrm{N}, 112^{\circ} 00^{\prime} \mathrm{E}, 17$ Aug. 2011, Mamontov 112-2 (MHA); same uplands, valley of Sokhondo River, $1205 \mathrm{~m}$ alt., $49^{\circ} 30^{\prime} \mathrm{N}, 111^{\circ} 04^{\prime} \mathrm{E}, 23$ Aug. 2011, Mamontov 166-6 (VBGI), 166-8-1 (MHA), 166-8-2 (NICH), 166-8-3 (KPABG); same uplands, Atsinsckiy Range, upper reaches of Vankina Brook, $1466 \mathrm{~m}$ alt., $50^{\circ} 09^{\prime} \mathrm{N}, 109^{\circ} 09^{\prime} \mathrm{E}, 11$ Aug. 2011, Mamontov 94-1 (LE), 94-2 (MO) 94-10-3 (KPABG), 94-11-1 (G), 948-1 (JE); Malkhanskiy Range, Cheremkhovo Pass, valley of Vyezdzhaya Brook, $1181 \mathrm{~m}$ alt., $50^{\circ} 44^{\prime} \mathrm{N}$, $110^{\circ} 22^{\prime}$ E, 13 Aug. 2011, Mamontov 104-2-1 (G), 1042-2 (GOET), 104-3-2 (VBGI), 104-3-3 (KPABG); same place, $1360 \mathrm{~m}$ alt., $50^{\circ} 44^{\prime} \mathrm{N}, 110^{\circ} 22^{\prime} \mathrm{E}, 14 \mathrm{Aug}$. 2011, Mamontov 105-2-6 (UBC); Daurskiy Range, $7 \mathrm{~km}$ NNE of Kaidalovo railway station, $755 \mathrm{~m}$ alt., $51^{\circ} 41^{\prime} \mathrm{N}, 114^{\circ} 00^{\prime} \mathrm{E}, 15$ July 2007 , Afonina $05307-4$ (SASY), 05307-6 (LE), 05307-7 (KPABG); same range, Aratsagon Mt., $956 \mathrm{~m}$ alt., $51^{\circ} 54^{\prime} \mathrm{N}, 114^{\circ} 25^{\prime} \mathrm{E}, 13$ July 2012, Mamontov 264-6-6 (MO), 264-11-1 (NY), 26411-2 (HSNU), 264-11-3 (MHA), 264-13-1 (KPABG), 264-18-2 (KPABG), 264-7-1 (NY), 264-8-2 (MHA), 264-8-3 (NICH), 264-8-4 (LE), 264-8-5 (MW), 264-9-1 (LE), 264-9-2 (NICH), 264-9-3 (MHA), 264-9-4 (MW); same place, $813 \mathrm{~m}$ alt., 13 July 2012, Mamontov 265 3-12 (MHA), 265-5-2 (KPABG), 265-5-3 (KPABG), same place, $892 \mathrm{~m}$ alt., 13 July 2012, Mamontov 262-1-6 (NICH); same place, Czernyadjeva 2-12 (MHA); same range, $5 \mathrm{~km}$ to the east of Duldurga Settlement, EloRahanai Mt., $772 \mathrm{~m}$ alt., $50^{\circ} 50^{\prime} \mathrm{N}, 113^{\circ} 24^{\prime} \mathrm{E}, 13$ July 2006, Afonina 4006-2 (GOET), 4006-3 (MHA), 4006-4 (KPABG), 4006-5 (KPABG), 4006-6 (KPABG), 4006-7 (LE), 4006-8 (G); Kiya River near Schilka Town, 509 m. alt., $51^{\circ} 53^{\prime} \mathrm{N}, 115^{\circ} 58^{\prime} \mathrm{E}$., 17 July 2007, Afonina 06107
(LE); Cherskiy Range, road to Usugly settlement, $683 \mathrm{~m}$ alt., $52^{\circ} 33^{\prime} \mathrm{N}, 115^{\circ} 27^{\prime} \mathrm{E}, 15$ July 2012 , Mamontov 268-6-1 (MO), 268-6-2 (HSNU), 268-6-3 (TNS); Stanovoye Nagor'e Uplands, Kodar Range, valley of Srednij Sakukan River, 1300 m alt., $56^{\circ} 54^{\prime}$ N, $117^{\circ} 51^{\prime}$ E, 3 July 2013, Mamontov 352-1-1 (KPABG), 352-1-2 (G), 3523-1 (JE), 352-3-2 (NICH). - Republic of BuRYATIA: East Sayan Mts., Okinskoe Plateau, valley of Oka River, $1599 \mathrm{~m}$ alt., $52^{\circ} 08^{\prime} \mathrm{N}, 100^{\circ} 20^{\prime} \mathrm{E}, 11$ July 2015 , Mamontov 553-1-1 (KPABG), 553-1-2 (LE), 553-1-2 (MHA); Selenga River valley, $564 \mathrm{~m}$ alt., $51^{\circ} 32^{\prime} \mathrm{N}$, $107^{\circ} 20^{\prime}$ E, 25 July 2013, Mamontov 374-1-1 (KPABG); Naushki town surroundings, $721 \mathrm{~m}$ alt., $50^{\circ} 23^{\prime} \mathrm{N}$, $106^{\circ} 07^{\prime}$ E, 23 July 2013, Tubanova 01-13 (UUH). Primorye TERRITORY: Mikhajlovskij Range, $280 \mathrm{~m}$ alt., $43^{\circ} 51^{\prime} \mathrm{N}, 132^{\circ} 55^{\prime} \mathrm{E}, 3$ June 2010, Bakalin P-3-6a-10 (VBGI). MONGOLIA: Bulgan Province: Gurvanbulag District, Hogno-Hanuul, 1396 m alt., $47^{\circ} 26^{\prime} \mathrm{N}$, $103^{\circ} 44^{\prime} \mathrm{E}, 18$ June 2010, Choi M5046 (VBGI). - Tuv AIMAG: Erdene sum, valley of Terelj River, 15 June 1974, Golubkova \& Tsogt 29 (MHA); same district (aimag) Altanbulag sum, Khustai range, Khoshoot Mt., 23 July 2002, Tsegmed 13276 (MHA).

Note. Most of the collections of Cephaloziella konstantinovae are sterile; therefore, an identification key for sterile plants of Cephaloziella from the Holarctic characterized by outgrowths on the abaxial leaf face is provided. The key is based on the studied type specimens of Cephaloziella hunanensis W. E. Nicholson and Prionolobus matsuurai S. Hatt. - the synonyms of Cephaloziella microphylla - and also the type specimen of $C$. acantophora (S. Hatt.) S. Hatt., the specimens of $C$. massalongii, $C$. phyllacantha and $C$. spinicaulis housed in KPABG, VBGI and $\mathrm{LE}$, as well as the descriptions of the three latter species in Schuster (1980, 1988) and Damsholt (2002). The key distinctions of $C$. divaricata var. asperifolia, C. uncinata var. mamillosa R. M. Schust. \& Damsh. and C. mamillifera R. M. Schust. \& Damsh. are provided according to the descriptions in Schuster (1988); the key distinctions of C. subtilis (Lindenb. \& Gottsche) Steph. follow its description in Fulford (1976). It should be noted that some of morphological distinctions of C. mamillifera are questionable. Schuster (1988: 214) notes that $C$. mamillifera has 'Leaves ... entire-margined ...', but this statement contradicts illustrations presented in the same publication, 
particularly Figure 19: 2, 7-11, Figure 25: 3, 7 and Figure 26: 1, 2, 4, 16, where the leaves are toothed at the base or along the whole leaf margin.

\section{KEY TO MORPHOLOGICALLY SIMILAR SPECIES OF CEPHALOZIELLA FROM THE HOLARCTIC}

1. Stem armed throughout with numerous spine-like, simple or bifurcate, outgrowths 1-4 cells in height, arranged in longitudinal lines ...... C. spinicaulis

1. Stem without such spine-like outgrowths ..... 2

2. Stem armed with few and low, unicellular rounded outgrowths or short ridges .......... 3

2. Stem smooth . . . . . . . . . . . . . . . 4 4

3. Terminal branches, when present, Acromastigumtype, rarely Frullania-type. Dioecious . . . . . . . . . $\ldots \ldots \ldots \ldots \ldots \ldots \ldots$. aspecaulis

3* Terminal branches, when present, Frullania-type. Autoecious, but often sterile or pseudo-dioecious . . ..................... mamillifera

4. Apices of leaves and underleaves (at least in some) consisting of a long 1-celled, acute and hyaline, thorn-like and somewhat curved or hooked tooth

C. phyllacanta

4. Apices of leaves and underleaves not consisting of such thorn-like teeth $\ldots \ldots \ldots \ldots \ldots 5$

5. Abaxial leaf surface and leaf margins ciliate, with numerous spine-like, 1-3-cells-long cilia. Underleaves absent or obsolete .......... C. acantophora

5. Leaves not copiously ciliate. Underleaves present or absent ...................6 6

6. Almost all leaf cells dorsally projecting by high, acute or conical mamillae. Dorsal leaf surface with acute, 1(-2)-celled teeth. Underleaves vestigial to rather well developed, rarely absent. Autoecious. .............. microphylla

6. Cells of leaf base dorsally smooth or mamillose, or with outgrowths, remaining leaf cells smooth (not projecting) ................. 7

7. Leaf lobe apex acuminate, formed of (1-)2 superimposed cells. Outgrowths on dorsal leaf surface acute, conical to spiniform, of 1-2 superimposed cells, originated at base or near leaf sinus. Leaf margins at base usually with a few acute, $1-2$ cells long teeth, rarely entire. Underleaves present, frequently bilobed, lobes with one to several marginal teeth ......... ...................... massalongii

7. Leaf lobe usually ending in one cell. Outgrowths on dorsal leaf surface uni- to multicellular, obtuse to rounded, but not spiniform. Leaf margins with acute to obtuse unicellular teeth, or with obtuse to rounded teeth with multiple-row bases, or entire. Underleaves present or absent .......... 8

8. Cells of stem and leaves thin-walled, convex throughout. Leaves mostly unequally bilobed, margins crenulate or with remote, broadly obtuse teeth

......................... 9

8. Cells of stem and leaves more or less thick-walled. Leaves subequally bilobed, margins toothed with acute to obtuse cells ................ 10

9. Outgrowths on abaxial leaf surface usually unicellular. Underleaves absent on sterile shoots. Female bracts and bracteole strongly connate, forming a cup (North America: Mexico) .... . C. subtilis

9. Outgrowths on abaxial leaf surface usually multicellular. Underleaves present on sterile shoots, well-developed, up to 0.7 of leaf length. Female bracts and bracteoles entirely free from each other (North Asia: Russia, Mongolia)

C. konstantinovae

10. Leaf margins dentate in lower half. Dioecious ... $\ldots \ldots \ldots \ldots \ldots$. divaricata var. asperifolia

10* Leaf margins entire. Autoecious . . . . . . . . . . . $\ldots \ldots \ldots \ldots \ldots$. uncinata var. mamillosa

ACKNOWLEDGEMENTs. We cordially thank Dr. Vadim A. Bakalin and Dr. Tsogiin Tsegmed for lending their collections of Cephaloziella from the Russian Far East and Mongolia. We are grateful to Dr. Masami Mizutani (NICH) for sending us the type specimens of Cephaloziella acantophora, C. hunanensis and Prionolobus matsuurai. We are greatly indebted to Dr. Jochen Heinrichs, Dr. Michael Ignatov, Dr. Yelena Kossovich-Anderson, Dr. Matt Renner, Dr. Alexey Troitsky, and the reviewers of Polish Botanical Journal for helpful suggestions and language improvement. This study was supported in part by the Russian Foundation for Basic Research (research project nos. 15-04-03479, 16-04-01156, 16-34-50278) and the Russian Federation President's Program for support of PhD researches (MK-3328.2011.4).

\section{REFERENCES}

Afonina O. M., Mamontov Yu. S. \& Czernyadjeva I. V. 2012. Mosses and liverworts of the Sokhondinsky State Reserve. Publishing house of LETU, St. Petersburg.

Arnell S. W. 1963. Hepaticae of South Africa. Swedish Natural Science Research Council, Stockholm.

Bakalin V. A. \& Vilnet A. A. 2014. Two new species of the liverwort genus Hygrobiella Spruce (Marchantiophyta) described from the North Pacific based on integrative taxonomy. Plant Syst. Evol. 300(10): 2277-2291. 
Crandall-Stotler B., Stotler R. E. \& Long D. G. 2009. Phylogeny and classification of the Marchantiophyta. Edinburgh J. Bot. 66(1): 155-198.

Czernyadjeva I. V., Mamontov Yu. S. \& Afonina O. M. 2013. On bryophyte flora of Atsinskiy Sanctuary (Zabaikal'sky Territory, South Siberia). Arctoa 22: 217-222.

Damsholt K. 2002. Illustrated Flora of Nordic Liverworts and Hornworts. Nordic Bryological Society, Lund.

De Roo R. T., Hedderson T. \& Söderström L. 2007. Molecular insights into the phylogeny of the leafy liverwort family Lophoziaceae Cavers. Taxon 56(2): 301-314.

Douin C. 1908. La Pedicelle de la Capsule des Hepatiques. Bull. de la Soc. Bot. de France 55: 194-202, 270-277.

Douin C. 1920. La famille des Cepahloziellacees. Mémoires de la Société Botanique de France 29: 1-90.

Feldberg K., Heinrichs J., Schmidt A. R., VÁŇa J. \& SchneIDER H. 2013. Exploring the impact of fossil constraints on the divergence time estimates of derived liverworts. Plant Syst. Evol. 299: 585-601.

Fulford M. H. 1976. Manual of the leafy Hepaticae of Latin America. Part IV. Mem. New York Bot. Gard. 11: 393-535.

Goloboff P. A. 1994. NONA: A Tree Searching Program. Program and documentation. Published by the author, Tucuman, Argentina.

Gradstein S. R., Laenen B., Frahm J.-P., Schwarz U., Crandall-Stotler B., Engel J. J., Von Konrat M., StotLer R., Shaw B., Shaw A. J. 2014. On the taxonomic status of the enigmatic Phycolepidoziaceae (Marchantiophyta: Jungermanniales) with description of a new species, Phycolepidozia indica. Taxon 63(3): 498-508.

Grolle R. \& Vanden Bergen C. 1970. Un genre nouveau pour la famille des Cephaloziellaceae: Cephalojonesia Grolle. Rev. Bryol. Lichénol. 37: 763-767.

Hall T. A. 1999. BioEdit: a user-friendly biological sequence alignment editor and analysis program for Windows 95/98/ NT. Nucleic Acids Symposium Series. 41: 95-98.

Heinrichs J., Gradstein S. R., Wilson R. \& Schneider H. 2005. Towards a natural classification of liverworts (Marchantiophyta) based on the chloroplast gene rbcL. Cryptog. Bryol. 26: 131-150.

Hentschel J., Paton J. A., Schneider H. \& Heinrichs J. 2007. Acceptance of Liochlaena Nees and Solenostoma Mitt., the systematic position of Eremonotus Pearson and notes on Jungermannia L. s.l. (Jungermanniidae) based on chloroplast DNA sequence data. Plant Syst. Evol. 268: $147-157$.

InOUE H. 1973. Metacephalozia, a new genus of the Hepaticae. J. Hattori Bot. Lab. 37: 287-291.

Jones E. W. 1960. African Hepatics XIV. Some Cephaloziellas of lowland tropical Africa. Trans. Brit. Bryol. Soc. 3: $430-440$.
JoNES E. W. 1985. African Hepatics XXXV. Some new or littleknown species and some noteworthy records. J. Bryol. 13: 497-508.

Kass R. E. \& RAFTERY A. E. 1995. Bayes factors. Journal of the American Statistical Association 90: 773-795.

Keane T. M., Creevey C. J., Pentony M. M, Naughton T. J. \& MCInerney J. O. 2006. Assessment of methods for amino acid matrix selection and their use on empirical data shows that ad hoc assumptions for choice of matrix are not justified. BMC Evolutionary Biology 6: 29.

Kitagawa N. 1965. Cephaloziellaceae of Japan. Acta Phytotax. Geobot. 21: 107-116.

Kitagawa N. 1969. Studies on the Hepaticae of Thailand II. Cephalozia and Cephaloziella. J. Hattori Bot. Lab. 32: 290-306.

Konstantinova N. A. \& Afonina O. M. 2009. New liverwort records from Zabaikal'sky Territory. 3. Arctoa 18: 249-287.

Konstantinova N. A., Bakalin V. A., Andrejeva E. N., BezGodov A. G., Borovichev E. A., Dulin M. V. \& MAMonTOV YU. S. 2009. Checklist of liverworts (Marchantiophyta) of Russia. Arctoa 18: 1-64.

Newton M. A. \& Raftery A. E. 1994. Approximate Bayesian inference by the weighted likelihood bootstrap. Journal of the Royal Statistical Society, Ser. B 56: 3-48.

Nixon K. C. 2002. WinClada ver. 1.00.08. Published by the author, Ithaca, New York.

Paton J. A. 1999. The liverwort flora of the British Isles. Harley Books, Colchester.

Patzak S. D. F., Schäfer-Verwimp A., VáŇa J., Renner M. A. M., Peralta D. F., Heinrichs J. 2016. Chonecoleaceae (Lophocoleineae) is a synonym of Cephaloziellaceae (Cephaloziineae) and Rivulariella (Jungermanniineae) belongs to Scapaniaceae s.l. (Cephaloziineae). Phytotaxa 267(2): 91-102.

Ronquist F., Hülsenbeck J. P. \& Teslenko M. 2011. MrBayes version 3.2 Manual: Tutorials and Model Summaries. http://mrbayes.sourceforge.net/.

Ronquist F., Teslenko M., van der Mark P., Ayres D. L., Darling A., Höhna S., Larget B., Liu L., Suchard M. A. \& Hülsenbeck J. P. 2012. MrBayes 3.2: Efficient Bayesian phylogenetic inference and model choice across a large model space. Syst. Biol. 61: 539-542.

Schiffner V. F. 1893. Hepaticae. In: A. Engler \& K. Prantl (eds), Die Natürlichen Pflanzenfamilien 1(3): 1-141. Engelmann, Leipzig.

Schljakov R. N. 1979. Pechenochnye Mkhi Severa SSSR. 2. Izdatel'stvo Nauka, Leningrad.

SCHUMACKer R. \& VÁŇA J. 2005. Identification keys to the liverworts and hornworts of Europe and Macaronesia, 2nd ed. Sorus Publishing, Poznań. 
Schuster R. M. 1969. Studies on Hepaticae XLVI-XLVII. On Alobiella (Spr.) Schiffn. and Alobiellopsis Schust. Bull. Natl. Sci. Mus. Tokyo 12: 659-683.

SCHuster R. M. 1971. Studies on Cephaloziellaceae I-II. Nova Hedwigia 22: 1-266.

Schuster R. M. 1980. The Hepaticae and Anthocerotae of North America. 4. Columbia University Press, New York.

Schuster R. M. 1988. The Hepaticae of South Greenland. Nova Hedwigia 92: 1-223.

Schuster R. M. 1995. Studies on Cephaloziellaceae III. On Cephalomitrion Schust., gen. n. Nova Hedwigia 61(3-4): 547-559.

Schuster R. M. 1996. Studies on Cephaloziellaceae. IV. On New Zealand taxa. Nova Hedwigia 63: 1-61.

Schuster R. M. 2002. Austral Hepaticae. Part II. Nova Hedwigia 119: 1-606.

Schuster R. M. \& Damsholt K. 1974. The Hepaticae of West Greenland from ca. $66^{\circ} \mathrm{N}$ to $72^{\circ}$ N. Meddel. Grønland 199(1): 1-373.

Shaw B., Crandall-Stotler B., Váña J., Stotler R., von Konrat M., Engel J. J., Davis E. C., Long D. G., Sova P. \& Shaw A. J. 2015. Phylogenetic relationships and morphological evolution in a major clade of leafy liverworts (Phylum Marchantiophyta, Order Jungermanniales): Suborder Jungermanniineae. Syst. Bot. 40(1): 27-45.

Söderström L., De Roo R. \& Hedderson T. 2010. Taxonomic novelties resulting from recent reclassification of the Lophoziaceae/Scapaniaceae clade. Phytotaxa 3: 47-53.

SöDerström L., Hagborg A., von Konrat M., BartholomewBegan S., Bell D., Briscoe L., Brown E., Cargill D. C., Costa D. P., Crandall-Stotler B. J., Cooper E. D., Dauphin G., Engel J. J., Feldberg K., Glenny D., Gradstein S. R., He X., Heinrichs J., Hentschel J., Ilkiu-Borges A. L., Katagiri T., Konstantinova N. A., Larraín J., Long D. G., Nebel M., Pócs T., Felisa Puche F., Reiner-Drehwald E., Renner M. A. M., SassGyarmati A., Schäfer-Verwimp A., Moragues J. G. S., Stotler R. E., Sukkharak P., Thiers B. M., Uribe J., VÁŇa J., Villarreal J. C., Wigginton M., Zhang L. \& ZHU R.-L. 2016. World checklist of hornworts and liverworts. PhytoKeys 59: 1-821.
Taberlet P., Gielly L., Pautou G. \& Bouvet J. 1991. Universal primers for amplification of three non-coding regions of chloroplast DNA. Plant Molecular Biology 17: 1105-1109.

Tsegmed T. \& BaI X.-L. 2013. Contribution to the Hepatic flora of Mongolia. 2. Arctoa 22: 113-132.

Udar R. \& Kumar A. 1980. A new Cephaloziella from India. Miscelanea Bryologyca et Lichenologyca. 8: 137-139.

UdAR R \& Kumar A. 1982. Two new species of Cephaloziella from India. Lindbergia 8: 30-34.

UdAR R. \& NATH V. 1976. A new species of Cephaloziella Spruce, C. magna Udar et Nath sp. nov. from Sheetla Khet, Almora (Western Himalayas), India. Geophytology 6: 105-107.

VÁŇA J. \& MüLler F. 2003. Cephaloziella biokoensis sp. nov. (Marchantiopsida, Cephaloziellaceae), from the island of Bioko (Equatorial Guinea). Trop. Bryol. 24: 1-4.

VÁŇa J., Söderström L., Hagborg A. \& von Konrat M. 2012. Notes on early land plants today. 8 . New combinations and some lectotypifications in Mesoptychia. Phytotaxa 65: 52-56.

VÁŇA J., SÖDERStröm L., Hagborg A. \& von Konrat M. 2013. Notes on Early Land Plants Today. 40. Notes on Cephaloziellaceae (Marchantiophyta). Phytotaxa 112(1): 1-6.

Vilnet A. A., Konstantinova N. A. \& Troitsky A. V. 2010. Molecular insight on phylogeny and systematics of the Lophoziaceae, Scapaniaceae, Gymnomitriaceae and Jungermanniaceae. Arctoa 19: 31-50.

Vilnet A. A., Konstantinova N. A. \& Troitsky A. V. 2012. Molecular phylogeny and systematics of the suborder Cephaloziineae with special attention to the family Cephaloziaceae s.l. (Jungermanniales, Marchantiophyta). Arctoa 21: 113-132.

White T. J., Bruns T., LeE S. \& TAYlor J. 1990. Amplification and direct sequencing of fungal ribosomal RNA genes for phylogenetics. In: M. A. InNis, D. H. GELFAnd, J. J. SNINSKy \& T. J. White (eds), PCR protocols: a guide to methods and applications, pp. 315-322. Academic Press, San Diego. 